Jurnal Media Agribisnis Vol. 3 No. 1 Tahun 2018 Hal 12 - 20

Media Komunikasi Hasil Penelitian Bidang Ilmu Agribisnis

ISSN print 2587-7027

ISSN online 2541-6898

\title{
DAMPAK PROGRAM USAHA AGRIBISNIS PEDESAAN ( PUAP ) TERHADAP KEKUATAN EKONOMI PETANI DI DESA TANAH TUMBUH KECAMATAN RENAH MENDALUH KABUPATEN TANJUNG JABUNG BARAT
}

\author{
Mandala Saputra ${ }^{1)}$ dan Siti Abir Wulandari ${ }^{2}$ \\ ${ }^{1)}$ Alumni Program Studi Agribisnis Fakultas Pertanian Universitas Batanghari \\ ${ }^{2)}$ Program Studi Agribisnis, Fakultas Pertanian Universitas Batanghari \\ Jl. Slamet Riyadi, Broni Jambi. 36122. Telp. +62074160103 \\ ${ }^{2}$ email korespondensi : abir_wulandari@yahoo.com
}

\begin{abstract}
This research was conducted at Tanah Tumbuh Village Renah Mandaluh Subdistrict, Tanjung Jabung Barat Regency, in January 2017. The number of sample farmers in this research were 77 farmers, survey method was used to collect data. The research objectives were: 1) To know the description of PUAP program 2) To know the economic strength before and after the PUAP existing.Description analisis and wilcoxson test were applied in this research.The result of the research showed that before the existing of PUAP the farmers economic strength of the people in Tanah Tumbuh Village was still low, it can be seen from the income, farming development, and capital amenity, it can be seen from the data that there were 43 farmers with low economic strength and 34 farmers with moderate economic strenght none of farmers that showed high economic strenght. After the PUAP axisting economic strength had increased the majority of people have had economic strength in the medium category of 61 farmers, for the low category decreased to 13 farmers and there are even already high category as much as 3 farmers. It was showed that Rural Agribusiness Development Program called PUAP had a significant effect on the changing of economic strenght condition.
\end{abstract}

Keywords: Program, Farmers, Financial assistent, farming Development

\begin{abstract}
Abstrak
Penelitian ini dilakukan di Desa Tanah Tumbuh Kecamatan Renah Mandaluh Kabupaten Tanjung Jabung Barat, pada bulan Januari 2017. Petani sampel dalam penelitian ini sebanyak 77 RTP. Tujuan penelitian yaitu: 1) Mengetahui gambaran PUAP 2) Mengetahui gambaran kekuatan ekonomi petani sebelum dan sesudah adanya PUAP, 3) Mengetahui kekuatan ekonomi petani sebelum dan sesudah adanya PUAP. Alat analisis yang digunakan adalah uji wilcoxson. Hasil penelitian menunjukkan bahwa sebelumkehadiran PUAP kekuatan ekonomi masyarakat di Desa Tanah Tumbuh masih tergolong rendah. Hal tersebut terlihat dari pendapatan, pengembangan usaha, dan kemudahan mendapatkan modal yang masih rendah. Hal tersebut terlihat dari data terdapat 43 RTP yang kekuatan ekonomi rendah dan 34 RTP masyarakat yang kekuatan ekonomi sedang. Setelah adanya PUAP kekuatan ekonomi mengalami peningkatan yaitu mayoritas masyarakat telah memiliki kekuatan ekonomi yang dalam kategori sedang yaitu sebanyak 61 RTP, untuk kategori rendah mengalami
\end{abstract}


Jurnal Media Agribisnis Vol. 3 No. 1 Tahun 2018 Hal 12 - 20

Media Komunikasi Hasil Penelitian Bidang Ilmu Agribisnis

ISSN print 2587-7027

ISSN online 2541-6898

penurunan menjadi 13 RTP dan bahkan ada yang sudah kategori tinggi sebanyak

3 RTP. Disimpulkan bahwa Program Pengembangan Usaha Agribisnis Pedesaan (PUAP) berpengaruh signifikan terhadap perubahan kondisi kekuatan ekonomi di Desa Tanah Tumbuh.

Kata kunci : Petani , Program Pengembangan Usaha Agribisnis Pedesaan ( PUAP ) Kec. Renah Mendaluh

\section{PENDAHULUAN}

Indonesia merupakan negara pertanian, artinya pertanian memegang peranan penting dalam keseluruhan perekonomian nasional. Hal ini dapat ditunjukkan dari banyaknya penduduk atau tenaga kerja yang bekerja pada sektor pertanian. Peranan sektor pertanian sangatlah strategis, bukan saja dalam rangka mencapai swasembada pangan tetapi juga dalam rangka memperluas sumber devisa nonmigas. Lebih dari itu pembangunan pertanian memperluas lapangan pekerjaan di daerah pedesaan dan menaikkan pendapatan petani yang juga merupakan lapisan terbesar dalam masyarakat. Dalam upaya membangun sektor pertanian sebagai landasan perekonomian dan meningkatkan pendapatan rakyat kecil demi pemerataan hasil pembangunan, pemerintah Indonesia telah melaksanakan program - program pengkreditan yang ditujukan kepada petani dan pengusaha kecil sejak Repelita I. Ciri umum kredit program pemerintah adalah bersuku bunga murah, berjangka waktu cukup lama, memperoleh dana likuiditas dari bank sentral, dan resiko kreditnya ditanggung pemerintah. Karena kebijakan kredit pertanian seperti ini lazim dilaksanakan di negara berkembang selama lebih dari dua dasawarsa, maka sering disebut program kredit tradisional atau konvensional. Salah satu program kredit pertama adalah Program Usaha Agribisnis Pedesaan ( PUAP ).Untuk melaksanakan PUAP di Dapartemen Pertanian, Menteri Pertanian membentuk tim Pengembangan Usaha Agribisnis Pertanian melalui keputusan menteri pertanian (KEPMENTAN) nomor 545/Kpts/OT.160/9/2007. Anggaran dana berasal dari mentri pertanian yang dikhususkan untuk membantu permnodalan bagi usaha petani. Masalah paling dasar bagi sebagian besar petani Indonesia adalah masalah keterbatasan modal yang dimiliki oleh para petani. Permasalahan yang dihadapi dalam permodalan pertanian berkaitan langsung dengan kelembagaan selama ini, yaitu lemahnya organisasi tani, sistem dan prosedur penyaluran menyentuh kepentingan petani yang sebenarnya. Dalam rangka menanggulangi permasalahan tersebut, dicanangkan program Pengembangan Usaha Agribisnis Perdesaan (PUAP). Program ini bertujuan untuk membantu mengurangi tingkat kemiskinan dan menciptakan lapangan pekerjaan di perdesaan serta membantu penguatan modal dalam kegiatan usaha di bidang pertanian sehingga dapat meningkatkan kesejahteraan petani.

PUAP merupakan modal awal bagi Gabungan Kelompok Tani ( GAPOKTAN ) yang diharapakan bisa berputar kembali. Pemerintah menjelaskan memberikan PUAP dengan harapan di tahun pertama untuk budidaya tahun kedua untuk simpan pinjam, dan tahun ketiga diharapkan bisa membentuk Lembaga Keuangan Mikro Agribisnis (LKMA). Dari uraian diatas maka peneliti tertarik untuk meneliti Dampak Program Pengembangan 
Jurnal Media Agribisnis Vol. 3 No. 1 Tahun 2018 Hal 12 - 20

Media Komunikasi Hasil Penelitian Bidang Ilmu Agribisnis

ISSN print 2587-7027

ISSN online 2541-6898

Usaha Agribisnis Pedesaan (PUAP).Terhadap Peningkatan Kekuatan Ekonomi

Petani Di Desa Tanah Tumbuh Kecamatan Renah Mendaluh Kabupaten Tanjung Jabung Barat.

METODOLOGI PENELITIAN

Penelitian ini dilakukan Di Desa Tanah Tumbuh Kecamatan Renah Mendaluh Kabupaten Tanjabarat dengan pertimbangan dana PUAP telah diterima oleh petani sejak tahun 2015, fokus penelitian ini berkaitan dengan gambaran kegiatan PUAP dan perbedaan kekuatan ekonomi sebelum dan sesudah adanya PUAP. Pelaksaaan pengambilan data dilakukan bulan Januari 2017 Metode yang digunakan dalam pengumpulan data pada penelitian ini adalah menggunakan metode survey, yaitu penelitian dengan cara pengambilan sampel dari populasi dan menggunakan kuisioner sebagai alat pengumpulan data dan menjelaskan hubungan antara variable - variabel melalui pengujian hipotesis.

Data yang dikumpulkan terdiri atas data primer dan data skunder. Data primer yaitu data yang diproleh secara langsung dari responden dengan cara wawancara terstruktur dengan menggunakan kuisioner. Data sekunder yaitu data yang diambil dari literatur-literatur atau data yang ada di intansi terkait.

Penarikan sampel dilakukan mengindentifikasi masyarakat yang bermukim di Desa Tanah Tumbuh Kecamatan Renah Mendaluh Kabupaten Tanjung Jabung Barat. Menurut data desa jumlah penduduk desa yang berusaha tani tahun 2016 ada sebayak 333 KK Masyarakat yang di jadikan populasi adalah masyarakat yang berusahatani sebelum dan sesudah adanya PUAP. Dari total jumlah populasi tersebut,berdasarkan pertimbangan dalam teknik pengambilan sempel yang menyatakan bahwa jika jumlah populasi di atas 100, maka sampel diambil sebanyak $15 \%$ dan jika jumlah sampel dibawah 100 maka sampel diambil sebayak 50\%. Berdasarkan pendapat tersebut maka jumlah sampelyang diambil adalah 23\% dari $333 \mathrm{KK}$ yaitu sebayak $77 \mathrm{KK}$. Kemudian pengambilan besarnya sampel pada masingmasing kelompok tani di Desa Tanah Tumbuh digunakan metode sampel berdasakan acak kelompok Data hasil penelitian yang telah dikumpulkan disederhanakan dan ditabulasi, kemudian Data baru di hitung rata-rata frekuensi dan persentasenya kemudian dianalisis. Untuk melihat perubahan kekuataan ekonomi sebelum dan sesudah adanya PUAP di Desa dianalisis dengan menggunakan Uji Wilcoxson Match Pairs untuk sampel besar $(>25)$ maka distribusinya dianggap akan mendekati distribusi normal. Untuk itu digunakan Z sebegai uji statistiknya dengan rumus Dimana nilai Ztabel pada $1 / 2 \alpha$ $=0,025$ (uji 2 pihak) adalah sebesar 1,96 Hipotesis operasional yang diajukan adalah :

Ho : Tidak terdapat perbedaan kondisi kekuatan ekonomi di Desa Tanah Tumbuh sebelum dan sesudah keberadaan PUAP.

Ha : Terdapat perbedaan kondisi kekuatan ekonomi di Desa Tanah Tumbuh sebelum dan sesudah keberadaan PUAP. 
Jurnal Media Agribisnis Vol. 3 No. 1 Tahun 2018 Hal 12 - 20

Media Komunikasi Hasil Penelitian Bidang Ilmu Agribisnis

ISSN print 2587-7027

ISSN online 2541-6898

1.

HASIL DAN PEMBAHASAN

- Identitas Petani Sampel

Umur Petani Umur merupakan salah satu faktor penting yang dapat mempengaruhi kemampuan masyarakat dalam melaksanakan kegiatan. Dimana masyarakat yang masuk dalam kategori muda memiliki kemampuan fisik yang kuat sehingga dapat bekerja lebih cepat, sedangkan petani yang masuk dalam kategori tua memiliki kemampuan fisik yang sudah mulai lemah sehingga melakukan suatu kegiatan pun akan menjadi lambat. Dari hasil penelitian dapat diketahui bahwa umur petani berkisar antara 20 -60 tahun, dengan rata-rata umur 39 tahun, hal ini menunjukan bahwa semua responden berada pada kategori umur produktif, dan memiliki kemampuan fisik yang baik. Hal ini sejalan dengan pendapat tohir ( 1983 ) bahwa kelompok umur produktif seseorang berada pada jenjang 20 - 58 tahun.

Tingkat Pendidikan merupakan salah satu faktor yang dapat mempengaruhi masyarakat dalam menyerap berbagai informasi serta menerima inovasi-inovasi baru tentang berbagai hal terutama dalam inovasi pertanian. Dalam penelitian ini tingkat pendidikan yang diukur adalah tingkat pendidikan formal yang pernah diikuti dan diselesaikan oleh masyarakat. Kemauan dan kemampuan masyarakat dalam mengambil keputusan juga dipengaruhi oleh tingkat pendidikan formal masyarakat. Saridewi (2010), menyatakan bahwa tingkat pendidikan seseorang dapat mengubah pola pikir, daya penalaran yang lebih baik, sehingga makin lama seseorang mengenyam pendidikan akan semakin rasional.

Tingkat pendidikan petani sampelterbanyak berdasarkan tingkat pendidikan formal yang pernah diselesaikan petani adalah SMP yaitu sebanyak 33 RTP (42,86\%). Sedangkan petani dengan tingkat pendidikan formal dengan persentasi yang paling rendah adalah Sarjana dengan 7 RTP (9,09\%).

Banyaknya anggota keluarga dapat mendorongmasyarakat sebagai kepala keluarga untuk menjadi lebih giat bekerja dalam memenuhi kebutuhan keluarga. Disamping itu anggota keluarga juga dapat dijadikan sebagai tenaga kerja tambahan yang dapat membantu meringankan tugas kepala keluarga dalam melakukan usaha-usaha tambahan yang lain seperti dalam berusaha tani. Jumlah anggota keluarga petani berkisar 1-5 orang. dengan jumlah anggota keluarga 2 orang adalah yang terbanyak, yaitu sebanyak 30 RTP $(38,96 \%)$. Dan jumlah anggota keluarga 5 orang adalah $\backslash$ yang paling sedikit dengan jumlah 1 Rumah Tangga (1,30\%).

Pengalaman berusahatani menentukan berhasil tidaknya petani dalam pekerjaannya. Dari hasil penelitian di lapangan menunjukkan bahwa rata-rata petani sampel cukup berpengalaman dalam berusaha tani, hal ini terlihat dari lamanya petani melakukan usahatani di daerah penelitian. Masyarakat yang paling banyak adalah yang telah berusahatani selama 5-7 tahun dengan jumlah 34 RTP (48,05\%). Sedangkan masyarakat yang paling sedikit adalah masyarakat yang berusahatani selama 11-13 tahun dengan jumlah 2 RTP $(2,6 \%)$.

Keadaan ekonomi suatu keluarga petani akan mempengaruhi keinginannya untuk mencari pekerjaan yang lain untuk memenuhi kebutuhan keluarganya. Banyaknya jumlah keluarga dan tanggungan keluarga juga akan mempengaruhi 
Jurnal Media Agribisnis Vol. 3 No. 1 Tahun 2018 Hal 12 - 20

Media Komunikasi Hasil Penelitian Bidang Ilmu Agribisnis

ISSN print 2587-7027

ISSN online 2541-6898

keluarga petani untuk mencari pendapatan tambahan untuk memenuhi kebutuhan keluarga petani. Petani sampel mempunyai pekerjaan sebagai pelaku usaha tani sawah dan kebun. Dan jumlah dari petani sampel yang mempunyai pekerjaan sampingan sebanyak 29 RTP. Adapun jenis pekerjaan yang dilakukan petani adalah seperti PNS, honorer, wiraswasta, bengkel dan lain-lain.

Luas lahan yang dimiliki oleh petani akan sangat menentukan pendapatan yang akan diterima oleh petani. Dari hasil penelitian dilapangan menunjukkan bahwa rata-rata petani memiliki luas lahan antara 2,2-3,3 ha luas lahan

\section{Gambaran Pelaksanaan PUAP di Desa Tanah Tumbuh Kecamatan Renah Mendaluh Kabupaten Tanjung Jabung Barat.}

Desa Tanah Tumbuh merupakan desa yang memiliki potensi akan pertaniannya untuk tanaman perkebunan. Jenis tanaman yang ditanam di Desa Tanah Tumbuh yaitu karet dan sawit, dan hanya sebagian kecil untuk tanaman padi dan tanaman hortikultura. Pada tahun 2014, berawal dari adanya persamaan kepentingan diantara petani-petani yang ada di wilayah desa Tanah Tumbuh dalam hal komoditi tanaman perkebunan, dibentuklah kelompok tani. Dan sampai saat ini telah terbentuk 8 kelompok tani di desa Tanah Tumbuh yang menjadi 1 gapoktan yang bernama "Gapoktan Rukun Tani" dengan jumlah anggota sebanyak 333 orang. Data jumlah kelompok tani tersebut dapat dilihat pada Tabel 12 berikut:

Tabel 1. Daftar Nama dan Jumlah Kelompok Tani di Gapoktan Rukun Tani 2017

\begin{tabular}{lllc}
\hline No & Kelompok Tani & Jumlah \\
\hline 1 & Karya Tani & 35 \\
2 & Tani Perjuangan & 37 \\
3 & Mekar Sari & 58 \\
4 & Cengkih Bina Tani & 34 \\
5 & Gotong Royong & 34 \\
6 & Kakao Bina Tani & 38 \\
7 & Karet Bina Tani & 29 \\
8 & KWT Wanita Tani & 68 \\
\hline
\end{tabular}

Sumber: Data Penyuluh Kecamatan Renah Mendaluh 2017

Pada tanggal 24 April 20014 melalui bimbingan Petugas Penyuluh Pertanian, Gapoktan Rukun Tani dikukuhkan melalui rapat pengukuhan Gapoktan yang disahkan oleh Kepala desa dan Camat menjadi Gapoktan Rukun Tani dengan anggota 333 orang. Sebagai legalitas Gapoktan Rukun Tani telah dikukuhkan dihadapan Notaris tanggal 10 Mei 2014.

Total keseluruhan dana PUAP yang diterima Gapoktan Rukun Tani adalah sebesar Rp. 100.000.000,-. Sebagian besar dana tersebut dialokasikan dalam kegiatan simpan pinjam kepada petani untuk keperluan produksi atau untuk kegiatan pemasaran hasil dan usaha lainnya. Selain dialokasikan untuk simpan pinjam, dana PUAP juga digunakan untuk kegiatan penyediaan saprodi seperti 
Jurnal Media Agribisnis Vol. 3 No. 1 Tahun 2018 Hal 12 - 20

Media Komunikasi Hasil Penelitian Bidang Ilmu Agribisnis

ISSN print 2587-7027

ISSN online 2541-6898

pupuk, benih, dan obat-obatan. Penyaluran dana PUAP di Gapoktan Rukun Tani yang ditetapkan oleh anggota kelompok tani adalah berupa paket pinjaman berupa uang tunai dan juga dapat berupa barang, tergantung dari kebutuhan para anggota kelompok tani. Jumlah maksimal pinjaman bervariasi, disesuaikan dengan kebutuhan petani. Kisaran pinjaman dana PUAP adalah Rp. 500.000,- sampai Rp. 2.000.000,- untuk pinjaman pertama. Jika pengembalian pinjaman petani lancar maka pinjaman berikutnya dinaikkan menjadi kisaran Rp 1.000.000 sampai Rp. 3.000.000,-.

Bunga pinjaman yang disepakati oleh anggota adalah sebesar $1,8 \%$ per bulan, dengan waktu pengembalian maksimal selama 5 bulan. Cara pengembalian pinjaman bisa dilakukan per minggu, per bulan, ataupun dibayar setiap kali panen. Untuk mengontrol kegiatan ini setiap bulan diadakan audit yang diketahui semua pengurus dan anggota yang diawasi serta diketahui oleh tim pengawas yaitu perangkat desa, penyuluh pertanian, serta dinas terkait yang terlibat dalam program tersebut.

\section{Gambaran Kekuatan Ekonomi Petani Sebelum Dan Sesudah Adanya Program PUAP di Desa Tanah Tumbuh Kecamatan Renah Mendaluh Kabupaten Tanjung Jabung Barat.}

Berhasil atau tidaknya Program Pengembangan Usaha Agribisnis Pedesaan (PUAP) dalam menggerakkan kondisi kekuatan ekonomi masyarakat tani tergantung pada kegiatan yang dilakukan oleh gapoktan dalam mengolah program PUAP menjadi kegiatan yang dapat meningkatkan kesejahteraan masyarakat terutama dalam meningkatkan kekuatan ekonomi masyarakat tani di Desa Tanah Tumbuh. Pelaksanaan program PUAP diharapkan dapat menimbulkan perubahan yang nyata dan positif terhadap kondisi kekuatan ekonomi masyarakat, karena dengan adanya perubahan ke arah yang positif maka akan mampu memperbaiki kondisi sosial ekonomi masyrakat.

Berdasarkan hasil penelitian dapat dilihat bahwa dengan adanya Program Pengembangan Usaha Agribisnis Pedesaan (PUAP) memberikan perubahan terhadap perubahan kekuatan ekonomi masyarakat yang bermukim di Desa Tanah Tumbuh. Perubahan yang ditimbulkan oleh program PUAP dapat dilihat dari kondisi pendapatan, pengembangan usaha, dan kemudahan mendapatkan modal sebelum dan sesudah adanya program PUAP Untuk lebih jelasnya dapat dilihat pada Tabel 2 berikut:

Tabel 2. Tabel Kondisi Kekuatan Ekonomi Sebelum Dan Sesudah Adanya PUAP

\begin{tabular}{ccc}
\hline & \multicolumn{3}{c}{ Kondisi kekuatan Ekonomi } \\
\hline Kategori & $\begin{array}{c}\text { Sebelum PUAP } \\
(\text { RTP) }\end{array}$ & $\begin{array}{c}\text { Sesudah PUAP } \\
(\text { RTP) }\end{array}$ \\
\hline Tinggi & 0 & 3 \\
Sedang & 34 & 61 \\
Rendah & 43 & 13 \\
\hline Jumlah & 77 & 77 \\
\hline
\end{tabular}

Sumber: Data Primer Diolah Tahun 2017 
Jurnal Media Agribisnis Vol. 3 No. 1 Tahun 2018 Hal 12 - 20

Media Komunikasi Hasil Penelitian Bidang Ilmu Agribisnis

ISSN print 2587-7027

ISSN online 2541-6898

Dari Tabel 2 Diatas dapat dilihat bahwa sebelum adanya PUAP kondisi kekuatan ekonomi masyarakat mayoritas rendah dengan jumlah 43 RTP sedangkan sesudah adanya PUAP kekuatan ekonomi masyarakat meningkat dengan mayoritas masyarakat memiliki kekuatan ekonomi sedang dengan jumlah 61 RTP.

Kondisi pendapatan, pengembangan usaha dan kemudahan mendapatkan modal sebelum adanya Program Pengembangan Usaha Agribisnis Pedesaan (PUAP) masuk dalam kategori rendah. Hal tersebut dapat dilihat pada bahwa dari 77 orang petani sampel terdapat 43 masyarakat tani yang memiliki kondisi kekuatan ekonomi yang rendah dan terdapat 34 masyarakat tani yang memiliki kondisi kekuatan ekonomi yang sedang serta tidak terdapat masyarakat yang memiliki kondisi kekuatan ekonomi yang tinggi. Hal tersebut jika ditarik kesimpulan bahwa rata-rata masyarakat tani masih memiliki kondisi kekuatan ekonomi yang rendah.

\section{Kekuatan Ekonomi Petani di Desa Tanah Tumbuh Kecamatan Renah Mendaluh Kabupaten Tanjung Jabung Barat.}

Secara keseluruhan dapat dilihat bahwa kondisi kekuatan ekonomi masyarakat desa Tanah Tumbuh mengalami perubahan pada saat sebelum dan sesudah adanya Program Pengembangan Usaha Agribisnis Pedesaan (PUAP). Hal ini terbukti dari hasil analisis Uji Wilcoxon terhadap kondisi kekuatan ekonomi masyarakat petani yang bermukim di Desa Tanah Tumbuh yaitu $Z$ hitung sebesar -7,62 yang lebih kecil dari harga $Z$ tabel sebesar $-1,96$ pada taraf signifikan $\alpha=0,05$. Hal ini berarti diperoleh keputusan untuk menolak hipotesis nol (Ho) atau menerima hipotesis alternatif (Ha), dengan demikian dapat disimpulkan bahwa Program Pengembangan Usaha Agribisnis Pedesaan (PUAP) berpengaruh terhadap perubahan kondisi kekuatan ekonomi di Desa Tanah Tumbuh. Dan untuk melihat dengan jelas perubahan dari tiap aspek dapat dijelaskan sebagai berikut:

\section{Perbedaan Kondisi Pendapatan di Desa Tanah Tumbuh Berdasarkan Tes Wilcoxon}

Hasil uji terhadap perubahan kondisi pendapatan sebelum dan sesudah adanya Program Pengembangan Usaha Agribisnis Pedesaan (PUAP) menghasilkan $\mathrm{Z}$ hitung sebesar -7,62 yang lebih kecil dari harga $\mathrm{Z}$ tabel sebesar 1,96 pada taraf signifikan $\alpha=0,05$. Hal ini berarti diperoleh keputusan untuk menolak hipotesi nol (Ho) atau menerima hipotesis alternatif $(\mathrm{Ha})$, dengan demikian dapat disimpulkan bahwa Program Pengembangan Usaha Agribisnis Pedesaan (PUAP) berpengaruh terhadap perubahan kondisi pendapatan masyarakat tani di Desa Tanah Tumbuh. Dari kondisi penghasilan terjadi peningkatan pendapatan masyarakat karena adanya penyediaan peminjaman modal sehingga masyarakat tani bisa membeli pupuk dan melakukan pemupukan tepat waktu, sehingga produksi dari tanaman meningkat yang akan menyebabkan pendapatan juga meningkat. 
Jurnal Media Agribisnis Vol. 3 No. 1 Tahun 2018 Hal 12 - 20

Media Komunikasi Hasil Penelitian Bidang Ilmu Agribisnis

ISSN print 2587-7027

ISSN online 2541-6898

\section{Perbedaan Kondisi Pengembangan Usaha di Desa Tanah Tumbuh Berdasarkan Tes Wilcoxon}

Hasil uji terhadap perubahan kondisi pengembangan usaha sebelum dan sesudah adanya Program Pengembangan Usaha Agribisnis Pedesaan (PUAP) menghasilkan $\mathrm{Z}$ hitung sebesar -7,62 yang lebih kecil dari harga $\mathrm{Z}$ tabel sebesar 1,96 pada taraf signifikan $\alpha=0,05$. Hal ini berarti diperoleh keputusan untuk menolak hipotesi nol (Ho) atau menerima hipotesis alternatif (Ha), dengan demikian dapat disimpulkan bahwa Program Pengembangan Usaha Agribisnis Pedesaan (PUAP) berpengaruh terhadap perubahan kondisi pengembangan usaha masyarakat tani di Desa Tanah Tumbuh. Dari kondisi pengembangan usaha terjadi peningkatan luas lahan usahatani hal ini disebabkan tersedianya modal untuk membuka lahan baru karena di desa Tanah Tumbuh masih banyak lahan yang belum digarap sehingga dengan tersedianya modal makin banyak lahan yang baru dibuka.

\section{Perbedaan Kondisi Kemudahan Mendapakan Modal di Desa Tanah Tumbuh Berdasarkan Tes Wilcoxon}

Hasil uji terhadap perubahan kondisi pendapatan sebelum dan sesudah adanya Program Pengembangan Usaha Agribisnis Pedesaan (PUAP) menghasilkan $\mathrm{Z}$ hitung sebesar $-5,79$ yang lebih kecil dari harga $\mathrm{Z}$ tabel sebesar 1,96 pada taraf signifikan $\alpha=0,05$. Hal ini berarti diperoleh keputusan untuk menolak hipotesi nol (Ho) atau menerima hipotesis alternatif (Ha), dengan demikian dapat disimpulkan bahwa Program Pengembangan Usaha Agribisnis Pedesaan (PUAP) berpengaruh terhadap kemudahan mendapatkan modal bagi masyarakat tani di Desa Tanah Tumbuh. Kemudahan mendapatkan modal tersebut disebabkan oleh telah tersedianya gapoktan yang mengelola dana Program Pengembangan Usaha Agribisnis Pedesaan (PUAP) menjadi tempat penyediaan peminjaman modal, sehingga memudahka masyarakat tani dalam memperoleh pinjaman untuk modal usaha.

\section{KESIMPULAN}

Berdasarkan hasil penelitian dan pembahasan dapat ditarik kesimpulan sebagai berikut:

1. Pelaksanaan Program PUAP di Desa Tanah Tumbuh Kecamatan Renah Mandaluh Kabupaten Tanjung Jabung Barat telah dilakukan sejak Juli 2014. Program PUAP ini dijalankan oleh Gapoktan Rukun Tani yang terdiri dari 8 kelompok tani serta anggota sebanyak 333 RTP. Dana yang diterima oleh gapoktan adalah sebesar Rp 100.000.000.-- Adapun dana tersebut dikelola oleh gapoktan sebagian besar untuk kegiatan simpan pinjam untuk modal usaha petani, dan untuk penyediaan sarana produksi untuk petani.

2. Kondisi kekuatan ekonomi pada Desa Tanah Tumbuh sebelum adanya Program Pengembangan Usaha Agribisnis (PUAP) yaitu kategori rendah sebanyak 43 RTP, kategori sedang sebanyak 34 RTP, dan tidak ditemukan masyarakat yang mempunyai kekuatan ekonomi yang tinggi. Sedangkan sesudah adanya Program Pengembangan Usaha Agribisnis (PUAP) kategori rendah berkurang menjadi 13 RTP, kategori sedang mengalami kenaikan 
Jurnal Media Agribisnis Vol. 3 No. 1 Tahun 2018 Hal 12 - 20

Media Komunikasi Hasil Penelitian Bidang Ilmu Agribisnis

ISSN print 2587-7027

ISSN online 2541-6898

menjadi 61 RTP, dan untuk kategori tinggi juga mengalami peningkatan menjadi 3 RTP.

3. Dampak adanya Program Pengembangan Usaha Agribisnis (PUAP) terhadap perubahan kondisi kekuatan ekonomi masyarakat yang bermukim di Desa Tanah Tumbuh, secara uji statistik memberikan pengaruh yang signifikan.

\section{DAFTAR PUSTAKA}

Akbar. 2011. Strategi Keberlanjutan Program Pengembangan Usaha Agribisnis Perdesaan (PUAP) (Kasus Kabupaten Karawang). Tesis. Institut Pertanian Bogor. Bogor.

Bappenas. 2004. Penanggulangan Kemiskinan. Jakarta

Ismawan Bambang. 2003. Peran Lembaga Keuangan Mikro. Jurnal Ekonomi dan

Bisnis Indonesia Univeritas Gadjah Mada. Yogyakarta

Kementerian Pertanian. 2009. Informasi Anggaran Departemen Pertanian Tahun 2009 Sekretariat Jenderal Kementerian Pertanian. Jakarta

2011. Pedoman Umum Program Pengembangan Usaha Agribisnis Perdesaan (PUAP). Jakarta.

2009. Informasi Anggaran Departemen Pertanian Tahun 2009. Sekretariat Jenderal Kementerian Pertanian. Jakarta.

Mahaga Radiana. 2009. Evaluasi Dampak Program Penanggulangan Kemiskinan Tahap 2 (P2KP-2) di Jawa Barat terhadap Tingkat Konsumsi Masyarakat. Tesis. Universitas Indonesia. Jakarta.

Pedoman PUAP. 2010. Kementrian Pertanian. Jakarta Prihantono. 2009. Dampak PUAP Terhadap Kinerja Gapoktan Dan Pendapatan Anggota Gapoktan Di Kabupaten Tanjung Jabung Barat. Universitas Jambi. Jambi

Situmorang Erlina. 2012. Modal Usaha dan Keberhasilan Pelaksanaan PUAP di Kabupaten Manokwari. Universitas Cendrawasih Papua. Papua

Soekartawi. 1995. Ilmu Usahatani dan Penelitian untuk Pengembangan Petani Kecil. Universitas Indonesia. Jakarta 1996. analisis Usahatani. Universitas Indonesia. Jakarta 